\title{
Enhanced student soft skills through integrated online project based collaborative learning
}

\author{
Sharifah Nadiyah Razali 1,2,*, Helmi Adly Mohd Noor ${ }^{3}$, Mohd Hafiez Ahmad ${ }^{4}$, Faaizah Shahbodin 2,5 \\ ${ }^{1}$ System Support and Networking Department, Kolej Komuniti Selandar, Melaka, Malaysia \\ ${ }^{2}$ Faculty of Information and Communication Technology, Universiti Teknikal Malaysia, Melaka, Malaysia \\ ${ }^{3}$ Research and Innovation Section, Malaysian Institute of Industrial Technology, Universiti Kuala Lumpur, Universiti Kuala \\ Lumpur, Johor, Malaysia \\ ${ }^{4}$ Electrical Installation Department, Kolej Komuniti Bukit Beruang Melaka, Malaysia \\ ${ }^{5}$ Centre of Technopreneurship Development, Universiti Teknikal Malaysia, Melaka, Malaysia
}

\section{ARTICLE IN F O}

\section{Article history:}

Received 4 November 2016

Received in revised form

16 January 2017

Accepted 18 January 2017

\section{Keywords:}

Collaborative learning

Learning management system

Facebook

Project based learning

\begin{abstract}
A B S T R A C T
This study aims to evaluate the effectiveness of Online Project Based Collaborative Learning (OPBCL) model in enhancing students' soft skills. This study involves qualitative and quantitative methods and using quasiexperimental designed which involves 106 respondents from Malaysian Polytechnic. Pre and post-test with non-equivalent control group design were used for this study. The respondents were divided into three groups called Control, Treatment I and Treatment II group where their soft skills are assessed for comparison between traditional project based learning method (Control), online project based learning using CIDOS platform (Treatment I) and online project based learning using OPBCL platform (Treatment II). In this study, OPBCL prototype was developed based on proposed model. The effectiveness of OPBCL prototype was assessed using Pre and post soft skills test (SST). All collected data were analysed using SPSS 19.0 software. Inferential analysis was intended to test the type of non-parametric such Kruskal Wallis, Mann Whitney and Wilcoxon Sign Rank Test. Findings from the pre and post soft skill indicated that all groups had positive effects on the soft skills of the students but in terms of the more successful group, the results showed that Treatment II is more success than Control group followed by Treatment I group. In addition, analysing the pre and post soft skills test of the critical thinking and problem solving (CTPS), collaboration (CS) and communication (CM) skills showed that for CTSP skill, Treatment II is more success than Control group followed by Treatment I group. Meanwhile for CL skill, there is no significant difference between Treatment I and Treatment II group. However, both treatment groups are more success than Control group. For CM skill, there is no significant difference between Control and Treatment II group. However, both Control and Treatment II groups are more success than Treatment I group. In conclusion, this study was able to provide evidence on students' soft skills enhanced via OPBCL model.
\end{abstract}

(C) 2017 The Authors. Published by IASE. This is an open access article under the CC BY-NC-ND license (http://creativecommons.org/licenses/by-nc-nd/4.0/).

\section{Introduction}

Education is important in contributing towards the future formation of an individual in the national development agenda. Through education, the development of human capital in terms of

\footnotetext{
* Corresponding Author.

Email Address: shnadiyah@yahoo.com (S. N. Razali)

https://doi.org/10.21833/ijaas.2017.03.010

2313-626X/C 2017 The Authors. Published by IASE.

This is an open access article under the CC BY-NC-ND license

(http://creativecommons.org/licenses/by-nc-nd/4.0/)
}

knowledge, skills and attitudes can be formed. Albano (2012) and Othman (2012) emphasise that the employability asset consists of knowledge, skills and attitudes. With globalization there is a big wave of change in the skills demand by employers. Most employers today look for soft skills rather than academic achievement as the primary criteria for the election of employee (Ismail et al., 2011). According to Al-Mamun (2012) soft skills is crucial for the enhancement of employment performance and career prospects. Higher Education Institutions (HEIs) are confronted with the challenge of producing graduates who meet the needed skills of 
employers. Therefore, the development of soft skills in a study plan is extremely needed. 21st century graduates are required to be equipped with skills that include critical thinking, problem solving, collaboration and communication.

Collaborative Learning (CL) has been proven to promote soft skills (Ada, 2009; Lee and Lim, 2012; Filigree, 2012; Sancho et al., 2011; Kabilan et al., 2011; Ahmad et al., 2011). Previous literature (Hennessey and Dionigi, 2013; Gillies and Boyle, 2010) and this study preliminary findings show that CL has been widely implemented in teaching and learning. Then again, question arises as to why students' mastery of soft skills is reported to be low. This indicates that although CL is implemented widely in the teaching and learning process, it does not often naturally happen in a group. It is difficult to monitor and at the same time to evaluate the CL process as CL activities are mostly conducted outside class time. Swan et al. (2006), Brindley et al. (2009) and Andresen (2009) stated that the evaluation of students' contributions in group work encourage them to participate actively in group activities. This is also helpful in overcoming the free rider issue which is often mentioned by previous researchers (Mohamad et al., 2013; Balliet, 2010). Here arises the importance of online platform for the facilitation of CL environments.

Each institution has its own Learning Management System (LMS) to manage the learning environments. LMS provides communication and collaboration that are featured in discussion boards or forums. LMS has been reported to be incapable of supporting interaction and communication and therefore this has led educators to utilise other applications as a replacement for a built-in discussion forum in LMS such Social Networking Sites (SNSs). Many researchers in the field of education have looked into the potential of adapting SNSs in their teaching and learning process (AlZoube, 2009; McCarthy, 2009; Marijana et al., 2011). Furthermore, various studies have focused on the integration of conventional LMS such as Moodle with SNSs. This has left a gap in the body of knowledge on how SNSs can be integrated into LMS platform to facilitate Online Collaborative Learning (OCL) which would promote the development of soft skills. Therefore, with the availability problem as stated, then the study to propose effective online learning environment that can facilitate Collaborative Learning is significant.

This research addresses the issue of soft skills deficiency among Malaysian Polytechnic graduates. Therefore, this study aims to enhance students' soft skills through integrated Online Project Based Collaborative Learning (OPBCL).

\section{Materials and methods}

\subsection{Methodology}

This study has been divided into three phases which are (i) Analysis; (ii) Design and Development; and (iii) Implementation and Evaluation. In the analysis phase, all factors and elements that affect the effectiveness of Online Collaborative Learning (OCL) were identified through document review and validated by experts (Sharifah et al., 2015; 2014). At the end of this phase, an OCL model was proposed model (Sharifah and Faaizah, 2015a). In the design and development phase, OPBCL was designed and developed based on the proposed model (Sharifah and Faaizah, 2015b). OPBCL was developed by integrating Moodle forum with Facebook function and using project-based learning approach.

In the implementation and evaluation phase, pilot study was conducted in order to ensure that all the instruments are valid and reliable. The test was performed by 32 respondents from Politeknik Ibrahim Sultan at the user's site. In general, a common used threshold value for acceptable reliability is 0.70 (Park, 2009). All measures fulfilled the suggested levels with composite reliability ranges from 0.742 to 0.951 . On the overall, the Alpha value was 0.935 . It can be concluded that all the values were good and had a high reliability (Zikmund and Babin, 2010). The results indicate that the prototype is ready to be tested in the real test. Furthermore, a quasi-experimental method will be conducted to obtain the data needed for this research.

\subsection{Respondents}

In this study, sample selection could not be done randomly because it could interfere with the students' schedules. The respondents are students who were takers of the Nutrition subject in the December 2014 session from Polytechnic Merlimau Melaka. A total of 106 students were involved in the real test. There were two classes namely control (52 students) and treatment (54 students) class. Then, for the treatment class, they were divided to two more groups known as treatment I and treatment II according to their tutorial class. Students involved in this study may be different in some aspects. These differences may affect the behaviour during the treatment given. In subject selection, any preexisting differences between the experimental and control groups (which may have resulted from a non-random sampling procedure) must be identified; otherwise differences between them can affect the research findings (Lee, 2012). Therefore, a pre-test was conducted to control the pre-existing differences between the intact groups. The post-test was used to assess the outcomes after intervention.

\subsection{Procedure}

A brief description about the study procedure was performed in week 8. All respondents completed a pre soft skills test before the intervention at the same time. Settings were done in week 8 (W8) and post soft skills test was conducted in week 17 (W17) after the intervention. Therefore, both group experienced the same development 
process. According to Madar (2009), the minimum duration for carrying out pre and post-test is 8 weeks because the duration given is sufficient to reduce the effects of the pre-test on the experimental results and conclusions. In this study, the time interval between the pre and post-test was 9 weeks. Training was given to both the treatment groups for two weeks (W12 and W13) to avoid differences in the ability to use the system. Each group received an equivalent amount of instructional time. The duration of the intervention lasted for 3 weeks (W14-W16) based on lecturer lesson plan and program syllabus. For the control group, students started do the project through traditional project collaborative learning method. Treatment I group started their project through CIDOS platform; meanwhile treatment II group started their project through OPBCL platform.

\section{Results and discussion}

A data distribution test was conducted to determine the subsequent analysis method (Saiyidi, 2015 ) and it is needed despite the small sample ( $\mathrm{n}<$ 30) always pass normality test (Öztuna et al., 2006). According to Ghasemi and Zahediasl (2012), the normal assumptions should be considered to verify the data presented. Kolmogorov-Smirnov (K-S) test is the main test to assess normality (Öztuna et al., 2006). According to K-S test $(n<2000)$ the pre and post soft skills of the student showed non-normal distribution (Table 1), it was determined that the Control group pre soft skills $(S=0.96, \mathrm{p}<0.05)$ and post soft skills ( $\mathrm{S}=0.84, \mathrm{p}<0.05)$, Treatment I group pre soft skills ( $\mathrm{S}=0.90, \mathrm{p}<0.005)$ and post soft skills ( $\mathrm{S}=0.5 .1, \mathrm{p}<0.05)$ and Treatment II group pre soft skills $(\mathrm{S}=0.83, \mathrm{p}<0.05)$ and post soft skills $(\mathrm{S}=$ $0.49, \mathrm{p}<0.05)$.

Table 1: Normality test of pre and post soft skills scores

\begin{tabular}{cccccccc}
\hline & \multirow{2}{*}{ Class } & \multicolumn{2}{c}{ Kolmogorov-Smirnova } & \multicolumn{3}{c}{ Shapiro-Wilk } \\
\cline { 2 - 7 } & Ctatistic & $\mathrm{df}$ & Sig. & Statistic & $\mathrm{df}$ & Sig. \\
\hline \multirow{3}{*}{ Pre soft skills } & Control & 0.15 & 52 & 0.00 & 0.96 & 52 & 0.05 \\
& Treatment I & 0.23 & 21 & 0.00 & 0.90 & 21 & 0.03 \\
& Treatment II & 0.26 & 33 & 0.00 & 0.83 & 33 & 0.00 \\
& & & & & & & \\
\multirow{3}{*}{ Post soft skills } & Control & 0.25 & 52 & 0.00 & 0.84 & 52 & 0.00 \\
& Treatment I & 0.48 & 21 & 0.00 & 0.51 & 21 & 0.00 \\
& Treatment II & 0.49 & 33 & 0.00 & 0.49 & 33 & 0.00 \\
\hline
\end{tabular}

The result indicated a non-normal distribution of data. Therefore, this study used the nonparametric test as a method of analysis. Accordingly, when comparing the pre and post soft skills, it was decided that the Wilcoxon Sign Rank test is used.

Table 2 shows a significant difference was found to exist between the pre and post soft skills for all groups. A pre and post soft skills measurement was taken on a scale where $0=$ Incompetent to $4=$ Exemplary. 52 students in the control group used the traditional platform and showed an increase soft skills after the measurement (Sum of Ranks = 1225.00), 21 students in Treatment I using CIDOS platform showed an increase soft skills after the measurement (Sum of Ranks $=231.00$ ) and 33 students in Treatment II group using OPBCL platform showed an increase soft skills in after measurement (Sum of Ranks $=561.00$ ). The Wilcoxon signed rank test shows that the observed differences between all groups measurement is significant for Control group $[\mathrm{z}=-6.120, \mathrm{~N}$-Ties $=3, \mathrm{p}$ $<0.05]$, Treatment I group $[\mathrm{z}=-4.042, \mathrm{~N}-$ Ties $=0, \mathrm{p}<$ $0.05]$ and Treatment II group $[\mathrm{z}=-5.077, \mathrm{~N}-\mathrm{Ties}=0$, $\mathrm{p}<0.05]$. Therefore, it appears that each group improved in the soft skills test. As such, it appears that control and treatment had positive effects on the soft skills of the students.

Table 2: Comparing pre and post soft skills scores

\begin{tabular}{ccccccc}
\hline Class & Post Soft Skills-Pre Soft Skills & $\mathrm{N}$ & Mean Rank & Sum of Ranks & $\mathrm{Z}$ & Asymp. Sig. (2-tailed) \\
\hline \multirow{5}{*}{ Control } & Negative Ranks & 0 & 0.00 & 0.00 & & \\
& Positive Ranks & 49 & 25.00 & 1225.00 & -6.12 & 0.00 \\
& Ties & 3 & & & & \\
Total & 52 & & & & \\
& Negative Ranks & 0 & 0.00 & 0.00 & & \\
Treatment I & Positive Ranks & 21 & 11.00 & 231.00 & -4.04 & \\
& Ties & 0 & & & & \\
& Total & 21 & & & & \\
& Negative Ranks & 0 & 0.00 & 0.00 & & \\
Treatment II & Positive Ranks & 33 & 17.00 & 561.00 & -5.07 & \\
& Ties & 0 & & & & \\
& Total & 33 & & & & \\
& & & &
\end{tabular}

Then, a Kruskal Wallis test was performed to determine which group was more success. Table 3 shows that significant difference existed among the post soft skills test scores $\mathrm{X}^{2}(2, \mathrm{n}=106)=23.89, \mathrm{p}<$
0.05. Based on this information, it was clear that the Treatment II group which participate using OPBCL platform (Mean Rank $=65.45$ ) were more successful than the Control group who merely participate using 
the traditional platform (Mean Rank $=57.07$ ) and Treatment I group which participated using CIDOS platform (Mean Rank $=25.88)$.

Table 3: Post soft skills test

\begin{tabular}{lcccccc}
\hline & Class & N & Mean Rank & Chi-Square & df & Asymp. Sig. \\
\hline \multirow{3}{*}{ Post Soft Skills } & Control & 52 & 57.07 & & & \\
& Treatment I & 21 & 25.88 & 23.89 & 2 & 0.00 \\
& Treatment II & 33 & 65.45 & & & \\
\hline
\end{tabular}

As a follow-up Mann-Whitney U-tests were conducted to evaluate pairwise differences among the Control, Treatment I and Treatment II group (Table 4). Results indicate a significant difference between the Control and Treatment I groups [U = 311.00, $\mathrm{z}=-2.91, \mathrm{p}<0.05$ ) in which Control group (Mean Rank $=41.52, \mathrm{n}=52$ ) had higher than Treatment I group (Mean Rank = 25.81, $\mathrm{n}=21$ ). For the second pair between Control and Treatment II groups indicated opposite results with no significant difference $[\mathrm{U}=808.50, \mathrm{z}=-0.47, \mathrm{p}>0.05)$ where Treatment II group (Mean Rank $=44.50, \mathrm{n}=33$ ) and Control group (Mean Rank = 42.05, $\mathrm{n}=52$ ). The third pair is between Treatment I and Treatment II groups, the result also indicated a significant difference $[\mathrm{U}=1.50, \mathrm{z}=-6.69, \mathrm{p}<0.05)$ in which
Treatment II group had higher (Mean Rank = 37.95, $n=33$ ) than Treatment I group (Mean Rank =11.07, $\mathrm{n}=21$ ). Therefore, it can be concluded that the OPBCL platform (Treatment II) improved the student's soft skills more than the use of CIDOS platform (Treatment I) and the traditional platform (control) also improved the students' soft skills more than the use of CIDOS platform (Treatment I). But, there are no differences between traditional (Control) and OPBCL platform (Treatment II) based on students' soft skills. In addition, analysing the pre and post soft skills test of the critical thinking, collaboration and communication skills of each group might be beneficial in determining the effect in terms of the performed activities.

Table 4: Pair wise different of post soft skills test

\begin{tabular}{ccccccc}
\hline & Class & $\mathrm{N}$ & Mean Rank & Mann-Whitney U & Z & Asymp. Sig. (2-tailed) \\
\hline \multirow{2}{*}{ Pair 1 } & Control & 52 & 41.52 & 311.00 & -2.91 & 0.00 \\
& Treatment I & 21 & 25.81 & & & \\
\multirow{2}{*}{ Pair 2 } & Control & 52 & 42.05 & 808.50 & -0.47 & 0.64 \\
& Treatment II & 33 & 44.50 & & & \\
\multirow{2}{*}{ Pair 3 } & Treatment I & 21 & 11.07 & \multirow{2}{*}{0.500} & -6.69 & \\
& Treatment II & 33 & 37.95 & & & \\
\hline
\end{tabular}

A Wilcoxon Signed Rank test was conducted. According to Table 5, a significant difference was found to exist between the pre and post soft skills for all groups on Critical Thinking and Problem Solving (CTPS) skills. 52 students in Control group using the traditional platform showed an increase in CTPS skills after measurement (Sum of Ranks $=1176.00$ ), 21 students in Treatment I using CIDOS platform showed an increase in CTPS skills after measurement (Sum of Ranks $=45.00$ ) and 33 students in Treatment II group using OPBCL platform showed an increase in CTPS skills after measurement (Sum of Ranks $=561.00$ ). The Wilcoxon signed rank test shows that the observed differences between all group measurement is significant for Control group $[\mathrm{z}=-6.12, \mathrm{p}<0.05]$, Treatment I group $[\mathrm{z}=-2.72, \mathrm{p}<0.05]$ and Treatment II group $[\mathrm{z}=-5.14, \mathrm{p}<0.05]$. Therefore, it appears that each group improved in terms of the CTPS skill. As such, it appears that control, Treatment I and Treatment II had positive effects on the CTPS skills of the students.

Table 5: Comparing pre and post CTPS skills scores

\begin{tabular}{|c|c|c|c|c|c|c|}
\hline \multicolumn{2}{|c|}{ Post CTPS-Pre CTPS } & $\mathrm{N}$ & Mean Rank & Sum of Ranks & $\mathrm{Z}$ & Asymp. Sig. (2-tailed) \\
\hline & Negative Ranks & 0 & 0.00 & 0.00 & & \\
\hline Control & $\begin{array}{c}\text { Positive Ranks } \\
\text { Ties } \\
\text { Total }\end{array}$ & $\begin{array}{c}48 \\
4 \\
52\end{array}$ & 24.50 & 1176.00 & -6.12 & 0.00 \\
\hline Treatment I & $\begin{array}{c}\text { Negative Ranks } \\
\text { Positive Ranks } \\
\text { Ties } \\
\text { Total }\end{array}$ & $\begin{array}{c}0 \\
9 \\
12 \\
21\end{array}$ & $\begin{array}{l}0.00 \\
5.00\end{array}$ & $\begin{array}{c}0.00 \\
45.00\end{array}$ & -2.72 & 0.01 \\
\hline Treatment II & $\begin{array}{c}\text { Negative Ranks } \\
\text { Positive Ranks } \\
\text { Ties } \\
\text { Total }\end{array}$ & $\begin{array}{c}0 \\
33 \\
0 \\
33\end{array}$ & $\begin{array}{c}0.00 \\
17.00\end{array}$ & $\begin{array}{c}0.00 \\
561.00\end{array}$ & -5.14 & 0.00 \\
\hline
\end{tabular}

A Wilcoxon Signed Rank test was conducted in this phase. According to Table 6, a significant difference was found to exist between the pre and post soft skills for all groups on collaboration skills. 
52 students in Control group using traditional platform showed an increase in collaboration skills after measurement (Sum of Ranks = 496.00), 21 students in Treatment I using CIDOS platform showed an increase in collaboration skills after measurement (Sum of Ranks $=231.00$ ) and 33 students in Treatment II group using OPBCL platform showed an increase in collaboration skills after measurement (Sum of Ranks $=561.00$ ). The
Wilcoxon signed rank test shows that the observed differences between all group measurement is significant for Control group [ $\mathrm{z}=-5.49, \mathrm{p}<0.05]$, Treatment I group $[\mathrm{z}=-4.29, \mathrm{p}<0.05]$ and Treatment II group $[z=-5.43, p<0.05]$. Therefore, it appears that each group improved in terms of the collaboration skills test. As such, it appears that control, Treatment I and Treatment II had positive effects on the collaboration skills of the students.

Table 6: Comparing pre and post collaboration skills scores

\begin{tabular}{|c|c|c|c|c|c|c|}
\hline \multicolumn{2}{|c|}{ Post CS-Pre CS } & $\mathrm{N}$ & Mean Rank & Sum of Ranks & $\mathrm{Z}$ & Asymp. Sig. (2-tailed) \\
\hline \multirow{4}{*}{ Control } & Negative Ranks & 0 & 0.00 & 0.00 & \multirow{4}{*}{-5.49} & \multirow{4}{*}{0.00} \\
\hline & Positive Ranks & 31 & 16.00 & 496.00 & & \\
\hline & Ties & 21 & & & & \\
\hline & Total & 52 & & & & \\
\hline \multirow{4}{*}{ Treatment I } & Negative Ranks & 0 & 0.00 & 0.00 & & \multirow{4}{*}{0.00} \\
\hline & Positive Ranks & 21 & 11.00 & 231.00 & -4.29 & \\
\hline & Ties & 0 & & & & \\
\hline & Total & 21 & & & & \\
\hline \multirow{4}{*}{ Treatment II } & Negative Ranks & 0 & 0.00 & 0.00 & & \multirow{4}{*}{0.00} \\
\hline & Positive Ranks & 33 & 17.00 & 561.00 & -5.43 & \\
\hline & Ties & 0 & & & & \\
\hline & Total & 33 & & & & \\
\hline
\end{tabular}

A Wilcoxon Signed Rank test was conducted. According to Table 7, a significant difference was found to exist between the pre and post soft skills for all groups on communication skills. 52 students in control group using traditional platform showed an increase communication skill after measurement (Sum of Ranks = 1128.00), 21 students in Treatment I using CIDOS platform showed an increase communication skill after measurement (Sum of Ranks $=210.00$ ) and 33 students in Treatment II group using OPBCL platform showed an increase communication skill after measurement (Sum of Ranks $=496.00$ ). The Wilcoxon signed rank test shows that the observed differences between all group measurement is significant for Control group $[\mathrm{z}=-6.11, \mathrm{p}<0.05]$, Treatment I group $[\mathrm{z}=-4.18, \mathrm{p}<$ 0.05] and Treatment II group [ $\mathrm{z}=-5.05, \mathrm{p}<0.05]$. Therefore, it appears that each group improved in terms of the communication skills test. As such, it appears that control and treatment had positive effects on the communication skills of the students.

Table 7: Comparing pre and post CM skills scores

\begin{tabular}{|c|c|c|c|c|c|c|}
\hline \multicolumn{2}{|c|}{ Post CM-Pre CM } & $\mathrm{N}$ & Mean Rank & Sum of Ranks & $\mathrm{Z}$ & Asymp. Sig. (2-tailed) \\
\hline Control & $\begin{array}{c}\text { Negative Ranks } \\
\text { Positive Ranks } \\
\text { Ties } \\
\text { Total }\end{array}$ & $\begin{array}{c}0 \\
47 \\
5 \\
52\end{array}$ & $\begin{array}{c}0.00 \\
24.00\end{array}$ & $\begin{array}{c}0.00 \\
1128.00\end{array}$ & -6.11 & 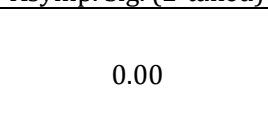 \\
\hline Treatment I & $\begin{array}{c}\text { Negative Ranks } \\
\text { Positive Ranks } \\
\text { Ties } \\
\text { Total }\end{array}$ & $\begin{array}{c}0 \\
20 \\
1 \\
21\end{array}$ & $\begin{array}{c}0.00 \\
10.50\end{array}$ & $\begin{array}{c}0.00 \\
210.00\end{array}$ & -4.18 & 0.00 \\
\hline Treatment II & $\begin{array}{c}\text { Negative Ranks } \\
\text { Positive Ranks } \\
\text { Ties } \\
\text { Total }\end{array}$ & $\begin{array}{c}0 \\
31 \\
2 \\
33\end{array}$ & $\begin{array}{c}0.00 \\
16.00\end{array}$ & $\begin{array}{c}0.00 \\
496.00\end{array}$ & -5.05 & 0.00 \\
\hline
\end{tabular}

Based on data as in the above (Table 5-7), it can be seen that the groups were differentiated in terms of the critical thinking and problem solving skills, collaboration skills and communication skills in the pre and post soft skills test. It can be concluded that all groups had positive effects on the critical thinking and problem solving skills, collaboration skills and communication skills of the students. Kruskal Wallis test must be performed to determine which group was more successful than the others.

Table 8 shows that a significant difference exists among the critical thinking and problem solving skills post scores $\mathrm{X}^{2}(2, \mathrm{n}=106)=52.96, \mathrm{p}<0.05$; collaboration skills post scores $X^{2}(2, n=106)=$ 24.17, $\mathrm{p}<0.05$ and communication skills post scores $\mathrm{X}^{2}(2, \mathrm{n}=106)=13.89, \mathrm{p}<0.05$. Based on this information, for critical thinking and problem solving skills it is revealed that the Treatment II group which participated using OPBCL platform (Mean Rank $=75.00)$ were more successful than control group which merely participated using traditional platform (Mean Rank $=53.85$ ) and Treatment I group which participated using CIDOS platform (Mean Rank = 18.86).

For collaboration skills it is revealed that the Treatment II group which participated using OPBCL 
platform (Mean Rank $=66.00)$ were more successful than Treatment I group which participated using CIDOS platform (Mean Rank $=61.00$ ) and control group which merely participate using traditional platform (Mean Rank = 42.54).

Meanwhile, as for communication skills it is revealed that the control group which merely participated using traditional platform (Mean Rank = 60.48) were more successful than Treatment II group which participated using OPBCL platform (Mean Rank $=56.05$ ) and Treatment I group which participated using CIDOS platform (Mean Rank = 32.21).

Table 8: CTPS, CS and CM skills post test

\begin{tabular}{|c|c|c|c|c|c|c|}
\hline Soft Skill & Class & $\mathrm{N}$ & Mean Rank & Chi-Square & $\mathrm{df}$ & Asymp. Sig. \\
\hline \multirow{3}{*}{ Critical Thinking and Problem Solving (CTPS) } & Control & 52 & 53.85 & \multirow{3}{*}{52.96} & \multirow{3}{*}{2} & \multirow{3}{*}{0.00} \\
\hline & Treatment I & 21 & 18.86 & & & \\
\hline & Treatment II & 33 & 75.00 & & & \\
\hline \multirow{3}{*}{ Collaboration (CS) } & Control & 52 & 42.54 & \multirow{3}{*}{24.17} & \multirow{3}{*}{2} & \multirow{3}{*}{0.00} \\
\hline & Treatment I & 21 & 61.00 & & & \\
\hline & Treatment II & 33 & 66.00 & & & \\
\hline \multirow{3}{*}{ Communication (CM) } & Control & 52 & 60.48 & \multirow{3}{*}{13.89} & \multirow{3}{*}{2} & \multirow{3}{*}{0.00} \\
\hline & Treatment I & 21 & 32.21 & & & \\
\hline & Treatment II & 33 & 56.05 & & & \\
\hline
\end{tabular}

Follow-up Mann-Whitney U-tests were conducted to evaluate the pairwise differences among the Control, Treatment I and Treatment II groups (Table 9). In critical thinking and problem solving skills, the results indicated a significant difference between the Control and Treatment I [U = 165.00, $\mathrm{z}=-4.91, \mathrm{p}<0.05$ ) whereby Control group had higher (Mean Rank $=44.33, \mathrm{n}=52$ ) than Treatment I (Mean Rank = 18.86, $\mathrm{n}=21$ ). For the second pair between Control and Treatment II also indicated a significant difference $[\mathrm{U}=495.00, \mathrm{z}=$ 4.02, $\mathrm{p}<0.05$ ) in which Treatment II had a higher (Mean Rank $=54.00, \mathrm{n}=33$ ) than Control (Mean Rank $=36.02, \mathrm{n}=52$ ). The third pair is between Treatment I and Treatment II and the results indicated a significant difference $[\mathrm{U}=.00, \mathrm{z}=-7.20, \mathrm{p}$ $<0.05$ ) in which Treatment II had higher (Mean Rank $=38.00, \mathrm{n}=33$ ) than Treatment I (Mean Rank= $11.00, \mathrm{n}=21$ ). Therefore, it can be concluded that the OPBCL platform improved the student's critical thinking and problem solving soft skill more than using traditional platform or CIDOS platform.

For collaboration skills, the results indicated a significant difference between the Control and Treatment I [ $\mathrm{U}=355.50, \mathrm{z}=-2.76, \mathrm{p}<0.05$ ) in which Treatment I had a higher (Mean Rank $=46.07, \mathrm{n}=21$ ) than Control (Mean Rank $=33.34, n=52$ ). For the second pair between Control and Treatment II also indicated a significant difference $[\mathrm{U}=478.50, \mathrm{z}=$ 4.39, $\mathrm{p}<0.05$ ) in which Treatment II had a higher (Mean Rank $=54.50, \mathrm{n}=33$ ) than Control (Mean Rank $=35.70, \mathrm{n}=52$ ). The third pair is between Treatment I and Treatment II, the results indicated non-significant difference $[\mathrm{U}=313.50, \mathrm{z}=-1.79, \mathrm{p}>$ 0.05 ) in which Treatment II (Mean Rank $=28.50, \mathrm{n}=$ 33) than Treatment I (Mean Rank $=25.93, \mathrm{n}=21$ ). Therefore, it can be concluded that the Treatment I and Treatment II platform improved the students' collaboration skills more than using Control platform. But, there is no significant difference between Treatment I and Treatment II.

For communication skills, the results indicated a significant difference between the Control and
Treatment I $[\mathrm{U}=357.00, \mathrm{z}=-2.44, \mathrm{p}<0.05$ ), which Control had higher (Mean Rank $=40.63, \mathrm{n}=52$ ) than Treatment I (Mean Rank $=28.00, \mathrm{n}=21$ ). For the second pair between Control and Treatment II there was no significant difference $[U=684.00, z=-1.65, p$ $>0.05$ ) in which Treatment II (Mean Rank $=37.73, \mathrm{~N}$ = 33) and Control (Mean Rank = 46.35, $\mathrm{n}=52$ ). The third pair is between Treatment I and Treatment II, and the results indicated a significant difference $[\mathrm{U}=$ 88.50, $\mathrm{z}=-5.10, \mathrm{p}<0.05$ ) which Treatment II had higher (Mean Rank $=35.32, \mathrm{n}=33$ ) than Treatment I (Mean Rank $=15.21, \mathrm{n}=21$ ). Therefore, it can be concluded that the OPBCL platform (Treatment II) improved the student's communication skills more than by using CIDOS platform and traditional platform (Control) improved the student's communication skills more than using CIDOS platform (Treatment I). However, there is no difference between Treatment II and control on communication soft skill.

The results showed that all groups had positive effects on the soft skills of the students. A Kruskal Wallis test was deemed necessary to determine which group was more successful. The results revealed that students' soft skills who received Treatment II intervention gained the most followed by Control group and the lowest increase is Treatment I group. Following this, Mann-Whitney Utests were conducted to evaluate the pairwise differences among the control, treatment I and treatment II group.

The findings indicated that Control group which used traditional platform enhanced students' soft skills more in comparison to the use of CIDOS platform by Treatment I group. This means that using traditional collaborative learning method is significantly better than treatment using online platform (CIDOS).

This finding is similar with a study conducted by Parsons et al. (2008), where traditional class was significantly better than the online class. Strømman (2015) found that the lack of social presences in 
participation.

Table 9: Pairwise soft skills differences among the control, treatment I and treatment II group

\begin{tabular}{|c|c|c|c|c|c|c|c|}
\hline Soft skill & & Class & $\mathrm{N}$ & Mean Rank & Mann-Whitney U & $\mathrm{Z}$ & Asymp. Sig. (2-tailed) \\
\hline \multirow{5}{*}{$\begin{array}{l}\text { Critical Thinking and } \\
\text { Problem Solving } \\
\text { (CTPS) }\end{array}$} & Pair 1 & Control & 52 & 44.33 & \multirow[t]{2}{*}{165.00} & \multirow[t]{2}{*}{-4.91} & \multirow{2}{*}{0.00} \\
\hline & Palr 1 & Treatment I & 21 & 18.86 & & & \\
\hline & Pair 2 & Control & 52 & 36.02 & 495.00 & -4.02 & 0.00 \\
\hline & \multirow{2}{*}{ Pair 3} & Treatment I & 21 & 11.00 & \multirow[b]{2}{*}{0.000} & \multirow[b]{2}{*}{-7.20} & \multirow[b]{2}{*}{0.00} \\
\hline & & Treatment II & 33 & 38.00 & & & \\
\hline \multirow{5}{*}{ Collaboration (CS) } & Pair 1 & Control & 52 & 33.34 & \multirow{2}{*}{355.50} & \multirow{2}{*}{-2.76} & \multirow{2}{*}{0.01} \\
\hline & \multirow{2}{*}{ Pair 2} & Treatment I & 21 & 46.07 & & & \\
\hline & & Control & 52 & 35.70 & 478.50 & -4.39 & 0.00 \\
\hline & \multirow{2}{*}{ Pair 3} & Treatment I & 21 & 25.93 & \multirow[b]{2}{*}{313.500} & \multirow[b]{2}{*}{-1.79} & \multirow[b]{2}{*}{0.07} \\
\hline & & Treatment II & 33 & 28.50 & & & \\
\hline \multirow{6}{*}{$\begin{array}{l}\text { Communication } \\
\text { (CM) }\end{array}$} & \multirow{2}{*}{ Pair 1} & Control & 52 & 40.63 & \multirow{2}{*}{357.00} & \multirow{2}{*}{-2.44} & \multirow{2}{*}{0.02} \\
\hline & & Treatment I & 21 & 28.00 & & & \\
\hline & \multirow{2}{*}{ Pair 2} & Control & 52 & 46.35 & \multirow{2}{*}{684.00} & \multirow{2}{*}{-1.65} & \multirow{2}{*}{0.10} \\
\hline & & Treatment II & 33 & 37.73 & & & \\
\hline & \multirow{2}{*}{ Pair 3} & Treatment I & 21 & 15.21 & \multirow{2}{*}{88.500} & \multirow{2}{*}{-5.10} & \multirow{2}{*}{0.00} \\
\hline & & Treatment II & 33 & 35.32 & & & \\
\hline
\end{tabular}

The failure of Online Collaborative Learning is because the platform could not provide similar platform as the traditional platform in order to facilitate a collaborative learning environment. This shows that, collaborative learning does not naturally happen in CIDOS in comparison to traditional faceto-face platform. Research by Sancho et al. (2011) showed that CL promotes the development of soft skills. However, if collaboration does not happen in a group, the development of soft skills will not happen. Therefore, educators must properly design their online platforms to make sure that it can facilitate Online Collaborative Learning.

Other findings indicated that the Treatment II enhanced the students' soft skills more than Treatment I. Even with the use of the same platform which is the online platform, Treatment II using OPBCL platform was significantly better than Treatment I using CIDOS platform. This confirmed that, CL does not naturally happen in CIDOS compared to OPBCL platform. OPBCL was developed by integrating LMS with the Facebook function to facilitate collaborative learning environment. This finding is supported by studies conducted by Petrovica et al. (2014), Thoms and Eryilmaz (2014), Iahad and Rahim (2012) where integration of LMS with SNSs functions can increase the quality of online learning.

However, there are no significant difference between Control and Treatment II based on students' soft skills. This shows that, OPBCL could provide an environment that is similar to the traditional environment. Different findings have been put forth by previous researchers. Some studies indicated that online learning is proven to be more effective than traditional learning (Nurbiha, 2012; Gratton and Stanley, 2009), while others report the opposite (Strømman, 2015; Figlio et al., 2010). Still others have reported that online learning as effective as traditional learning (Stack, 2015; Jacobs, 2013). This study supports all findings from previous studies. In addition, analysing the pre and post soft skills test of critical thinking and problem solving skills, collaboration skills and communication skills of each group might be beneficial in determining the effect in terms of the performed activities.

The Wilcoxon Signed Rank test results showed that all groups had positive effects on the critical thinking and problem solving skills, collaboration skills and communication skills of the students. Therefore, Kruskal Wallis test must be performed to determine which group is more successful than the other. For critical thinking and problem solving skills, it has been revealed that the Treatment II group which participated using OPBCL platform were more successful than Control group which merely participated using traditional platform, followed by Treatment I group which participated using CIDOS platform. For collaboration skills, it has been revealed that the Treatment II group which participated using OPBCL platform were also more successful than Treatment I group which participated using CIDOS platform, followed by Control group which merely participated using traditional platform. Meanwhile, for communication skills, it has been revealed that the Control group which merely participated using traditional platform were more successful than Treatment II group which participated using OPBCL platform, followed by Treatment I group which participated using CIDOS platform. Following this, Mann-Whitney U-tests were conducted to evaluate the pairwise differences among the Control, Treatment I and Treatment II group.

\section{Conclusion}

This study attempted to enhance students' core soft skills through Online Project Base Collaborative Learning (OPBCL), which was developed based on the proposed Online Collaborative Learning (OCL) model and Project Based Learning (PjBL) approach. 
OPBCL platform improved the students' critical thinking and problem solving skills more than by using traditional platform or CIDOS platform. This study supports both findings from previous studies where some research showed that traditional platform is better than online platform (Nurbiha, 2012; Gratton and Stanley, 2009) and vice versa (Parsons et al., 2008; Stack, 2015). Meanwhile, CIDOS and OPBCL platform improved the student's collaboration skills more than by using traditional platform. However, there is no difference in student's collaboration skills between CIDOS and OPBCL platform. Collaboration skills need students to participate and share information with others. Traditionally, students used technology to do research. But they have different ways of sharing the information. In the conventional way, students can print or bring softcopies when meeting in face-toface. However, in online learning, students easily share the knowledge through forum. They can send a file or link in forum. It can be concluded that online platform can assist to improve student collaboration skills.

OPBCL platform improved the students' communication skills more than by using CIDOS platform and traditional platform has improved the students' communication skills more than by using CIDOS platform. However, there is no difference between OPBCL and traditional platform on communication skills. This finding address on the issue that OCL cannot provide effective communication platforms such as traditional learning. The findings was supported by Simsek (2011) where educators should identify best practice in online learning that at least can be good as face-to-face learning. The failure of OCL is because the platform cannot provide similar platform as traditional in facilitating collaborative learning (Strømman, 2015). It can be concluded that OPBCL can provide similar platform as traditional in order to facilitate collaborative learning. Swan (2002) stated that "as long as the quality of instruction is delivered over distance it was as good as the quality of traditional education, and there would be no significant difference in learning between them".

In conclusion, this study has discovered some new information to understand the effects of Learning Management System (LMS) integration with Facebook function to enhance students' soft skills through Online Project Based Collaborative Learning (OPBCL). By considering several factors that can influence Online Collaborative Learning, student's soft skills can be enhanced. Technology and instructional design were found to be important aspects to increase student interaction.

\section{References}

Ada WWM (2009). Computer supported collaborative learning and higher order thinking skills: A case study of textile studies. Interdisciplinary Journal of E-Learning and Learning Objects, 5: 145-167.
Ahmad E, Jailani MY, and Aina AMA (2011). Developing soft skill in Advanced Technology Training Centre (ADTEC): An analysis of comparison. Educational Technology, 39: 48954904.

Albano G (2012). A knowledge-skill-competencies e-learning model in mathematics. Revista de Universidad y Sociedad del Conocimiento. 9(1): 306-319.

Al-Mamun MA (2012). The soft skills education for the vocational graduate: value as work readiness skills. British Journal of Education, Society and Behavioural Science, 2(4): 326-338.

Al-Zoube M (2009). E-Learning on the cloud. International Arab Journal of E-Technology, 1(2): 58-64.

Andresen MA (2009). Asynchronous discussion forums: Success factors, outcomes, assessments, and limitations. Educational Technology and Society, 12(1): 249-257.

Balliet D (2010). E-research collaboration and the free-rider problem: Communication solutions to social dillemas in computer mediated research collaboration. In: Murugan A (Eds.), E-Research Collaboration: Theory, Techniques and Challenges: 277-287. Springer Berlin, Heidelberg, Germany.

Brindley JEJ, Blaschke LML, and Walti C (2009). Creating effective collaborative learning groups in an online environment. International Review of Research in Open and Distributed Learning, 10(3): 1-18.

Figlio DN, Rush M, and Yin L (2010). Is it live or is it internet? Experimental estimates of the effects of online instruction on student learning. National Bureau of Economic Research, Cambridge, USA. Available online at: http://www.nber.org/ papers/w16089

Filigree C (2012). Instructional technology and collaborative learning best practices: Global report and recommendations. SMART Technologies, USA. Available online at: http://vault.smarttech.com/assessment/education_whitepap ers_web.pdf?WT.ac=edresearch.

Ghasemi A and Zahediasl S (2012). Normality tests for statistical analysis: A guide for non-statisticians. International Journal of Endocrinology and Metabolism, 10(2): 486-489.

Gillies RM and Boyle M (2010). Teachers' reflections on cooperative learning: Issues of implementation. Teaching and Teacher Education, 26(4): 933-940.

Gratton LC and Stanley D (2009). Teaching and learning principles of microeconomics online: An empirical assessment. Journal of Economic Education, 40(1): 3-25.

Hennessey A and Dionigi RA (2013). Implementing cooperative learning in Australian primary schools: Generalist teachers' perspectives. Issues in Educational Research, 23(1): 52-68.

Iahad A and Rahim A (2012). Acceptance and usage of ICT by university academicians using UTAUT model: A case study of University of Port Harcourt, Nigeria. Journal of Emerging Trends in Computing and Information Sciences, 3(1): 81-89.

Ismail R, Yussof I, and Sieng LW (2011). Employers' perceptions on graduates in Malaysian services sector. International Business Management, 5(3): 184-193.

Jacobs P (2013). The challenges of online courses for the instructor. Research in Higher Education Journal, 21: 1-19.

Kabilan MK, Adlina WFW, and Embi MA (2011). Online collaboration of English language teachers for meaningful professional development experiences. English Teaching, 10(4): 94-115.

Lee HJ and Lim C (2012). Peer evaluation in blended team projectbased learning: What do students find important? Educational Technology and Society, 15(4): 214-224.

Lee JH (2012). Experimental methodology in English teaching and learning: Method features, validity issues, and embedded experimental design. English Teaching, 11(2): 25-43. 
Madar AR (2009). Keberkesanan animasi grafik dalam kalangan pelajar berbeza gaya kognitif dan kebolehan visualisasi spatial di Politeknik. Ph.D. Thesis, Universiti Teknologi Malaysia, Johor.

Marijana DZ, Aleksandra BL, and Aleksandar RM (2011). Fostering engineering e-learning courses with social network services. In the $19^{\text {th }}$ Telecommunications Forum (TELFOR '11), Serbia, Belgrade: 122-125.

McCarthy J (2009). Utilising Facebook: Immersing Generation-Y students into first year university. Journal of the Education Research Group of Adelaide, 1(2): 39-50.

Mohamad SMNH, Forret M, and Eames C (2013). Online collaborative learning in tertiary ICT education: Constraints and suggestions for improvement. In the International Conference on Informatics and Creative Multimedia (ICICM), Kuala Lumpur, Malaysia: 153-158. https://doi.org/10.1109/ ICICM.2013.33

Nurbiha AS (2012). Cognitive engagement in computer supported collaborative learning environment. Universiti Teknologi Malaysia, Johor, Malaysia.

Othman MB (2012). Tahap kompetensi pelajar melaksanakan kerja amali berpandukan domain psikomotor simpson. M.Sc. Thesis, Universiti Tun Hussein Onn Malaysia, Johor, Malaysia.

Öztuna D, Elhan AH, and Tüccar E (2006). Investigation of four different normality tests in terms of type 1 error rate and power under different distributions. Turkish Journal of Medical Sciences, 36(3): 171-176.

Park SY (2009). An analysis of the technology acceptance model in understanding university students' behavioral intention to use e-learning research hypotheses. Educational Technology and Society, 12(3): 150-162.

Parsons PN, Diehl Lacks R, and Hylton GP (2008). A comparative assessment of student learning outcomes in large online and traditional campus-based introduction to criminal justice courses. Criminal Justice Studies, 21(3): 239-251.

Petrovica N, Jeremica V, Cirovica M, Radojicica Z, and Milenkovica $\mathrm{N}$ (2014). Facebook versus Moodle in practice. American Journal of Distance Education, 28(2): 117-125.

Saiyidi MR (2015). An analysis of insider dysfunctional behaviours in an accounting information system environment. Ph.D. Thesis, Edith Cowan University, Perth, Australia.
Sancho P, Torrente J, Marchiori EJ, and Fernández-Manjón B (2011). Enhancing moodle to support problem based learning: The Nucleo experience. In the IEEE Global Engineering Education Conference (EDUCON): 1177-1182. https://doi.org/10.1109/EDUCON.2011.5773296

Sharifah Nadiyah R, and Faaizah S (2015b). The development of online project based collaborative learning using ADDIE model. Procedia Social and Behavioral Sciences, 195: 18031812.

Sharifah Nadiyah R, Faaizah S, Hanipah H, and Norasiken B (2015). Online collaborative learning elements to propose an online project based collaborative learning model. Jurnal Teknologi, 77(23): 55-60.

Sharifah NR, Faaizah S, and Gede PA (2015a). A proposed model for online project based collaborative learning : Expert review. Journal of Network and Innovative Computing, 3: 1-6.

Sharifah NR, Faaizah S, Hanipah H, and Norasiken B (2014). Factors that affecting the effective online collaborative learning environment. In the $4^{\text {th }}$ World Congress on Information and Communication Technology: 293-302.

Simsek A (2011). Interview with Tony Bates on the aspects and prospects of online learning. Contemporary Educational Technology, 2(1): 88-94.

Stack S (2015). Learning outcomes in an online vs traditional course. International Journal for the Scholarship of Teaching and Learning, 9(1): 1-18.

Strømman E (2015). Participant activity and facilitator strategies in an LMS-based discussion forum. Nordic Journal of Digital Literacy, 9(1): 43-65.

Swan K (2002). Building learning communities in online courses: The importance of interaction. Education, Communication and Information, 2(1): 23-49.

Swan K, Shen J, and Hiltz SRS (2006). Assessment and collaboration in online learning. Journal of Asynchronous Learning Networks, 10(1): 45-62.

Thoms B and Eryilmaz E (2014). How media choice affects learner interactions in distance learning classes. Computers and Education, 75: 112-126.

Zikmund WG and Babin BJ (2010). Essentials of marketing research. $4^{\text {th }}$ Edition, South-Western, Australia. 